\title{
Reduction of Major Pollutants via Air-staged Commbustion on Burner System
}

\author{
Mohammad Nazri Mohd. Jaafara*, Mohd Nur Hanafi Zainia \\ ${ }^{a}$ Department of Aeronautical, Automotive and Ocean Engineering, Faculty of Mechanical Engineering, Universiti Teknologi Malaysia, 81310 UTM Johor \\ Bahru, Johor, Malaysia \\ *Corresponding author: nazri@fkm.utm.my
}

\section{Article history}

Received :9 April 2013

Received in revised form:

16 July 2013

Accepted :15 August 2013

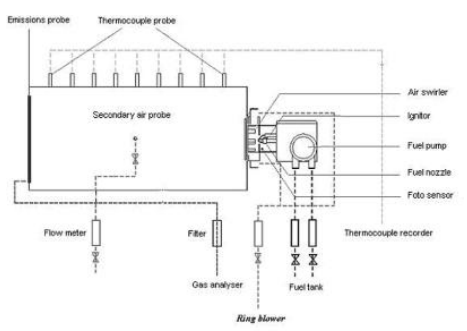

\section{Abstract}

Emission from the combustion processes can cause adverse effect to the environment. The formation of pollutants such as $\mathrm{NO}_{x}, \mathrm{CO}, \mathrm{CO}_{2}$ and $\mathrm{SO}_{x}$ are hazardous and harmful to the ecosystem. The awareness about the pollution due to the combustion activities, particularly in industrial field has set off an effort to find more comprehensive and enhanced technologies to reduce these pollutants. There are several methods that can be used to reduce the emissions of these pollutants either by combustion modifications or post combustion treatment. In this research, the method used is the post combustion treatment, i.e. the air staging method. By air staging techniques, some of the combustion air will be directed into the primary combustion zone, while the remaining air is directed into the secondary zone. The function of the secondary air is to reduce the peak flame temperatures, which theoretically reduce the emissions of $\mathrm{NO}_{\mathrm{x}}$ emissions. The primary concern for this research is to study the effectiveness of the air staging in reducing $\mathrm{NO}_{\mathrm{x}}, \mathrm{CO}, \mathrm{SO}_{2}$ and UHC emissions from the combustion process. The results obtained showed significant reduction in all major pollutants, i.e., a 31.8 percent reduction for $\mathrm{CO}$ emission, 16.8 percent for $\mathrm{NO}_{x}, 12.7$ percent for $\mathrm{SO}_{2}$ and 10.3 percent for UHC. These reductions were obtained at different equivalence ratios for different gases.

Keywords: Air staging; $\mathrm{NO}_{\times} ; \mathrm{CO} ; \mathrm{SO}_{2} ; \mathrm{UHC} ;$ emissions; oil burner

\begin{abstract}
Abstrak
Emisi dari proses pembakaran boleh mengakibatkan kesan buruk kepada alam sekitar. Pembentukan bahan cemar seperti $\mathrm{NO}_{\mathrm{x}}, \mathrm{CO}, \mathrm{CO}_{2}$ dan $\mathrm{SO}_{\mathrm{x}}$ adalah berbahaya dan memudaratkan ekosistem. Kesedaran tentang pencemaran yang disebabkan oleh aktiviti pembakaran, terutamanya dari sektor perindustrian telah mengorak usaha untuk mencari teknologi yang lebih menyeluruh dan dipertingkatkan untuk mengurangkan bahan cemar ini. Terdapat beberapa kaedah yang boleh digunakan untuk mengurangkan emisi bahan cemar sama ada dengan pengubahsuaian pembakaran atau rawatan pasca pembakaran. Dalam kajian ini, kaedah yang digunakan ialah rawatan pasca pembakaran, iaitu kaedah pemeringkatan udara. Melalui kaedah pemeringkatan udara, sebahagian udara pembakaran akan dimasukkan ke dalam zon pembakaran utama, manakala udara baki dimasukkan ke dalam zon sekunder. Fungsi udara sekunder adalah untuk mengurangkan suhu nyalaan puncak, yang secara teorinya mengurangkan penjanaan emisi $\mathrm{NO}_{\mathrm{x}}$. Objektif utama kajian ini adalah untuk melihat keberkesanan pemeringkatan udara dalam mengurangkan emisi $\mathrm{NO}_{\mathrm{x}}$, $\mathrm{CO}, \mathrm{SO}_{2}$, dan UHC dari proses pembakaran. Keputusan yang diperolehi menunjukkan pengurangan ketara dalam semua bahan cemar utama, iaitu, 31.8 peratus pengurangan bagi emisi $\mathrm{CO}, 16.8$ peratus bagi $\mathrm{NO}_{\mathrm{x}}$, 12.7 peratus bagi $\mathrm{SO}_{2}$ dan 10.3 peratus bagi UHC. Pengurangan ini telah diperolehi pada nisbah kesetaraan yang berlainan bagi bahan cemar yang berbeza.
\end{abstract}

Kata kunci: Pemeringkatan udara; $\mathrm{NO}_{\mathbf{x}} ; \mathrm{CO} ; \mathrm{SO}_{2} ; \mathrm{UHC}$; emisi; pembakar minyak

\subsection{INTRODUCTION}

The need to protect the environment from combustion generated $\mathrm{NO}_{\mathrm{x}}$ has led to considerable demand to improve burner design. Previously, attention has been given to gas turbine used in aero engines and for power generation in stationary plant. Intense research has been going on to develop gas turbine with very low $\mathrm{NO}_{\mathrm{x}}$ emissions. In recent years considerable attention has been paid to reducing $\mathrm{NO}_{\mathrm{x}}$ from process burners. However, in order to minimize $\mathrm{NO}_{\mathrm{x}}$ emissions from gas turbine combustor it is necessary to increase the primary zone airflow and to improve air and fuel mixing. Many low-emission gas turbine combustor 
designs aim to pass as much air as possible through the combustor head and add the remaining air further downstream in a dilution zone with no air needed for film cooling [1]. The primary zone is a burner configuration. Thus, many of the methods used to effectively minimize $\mathrm{NO}_{\mathrm{x}}$ emissions from gas turbine can be adapted to burner configurations and conditions.

The effects of increased levels of $\mathrm{NO}_{\mathrm{x}}$ in the atmosphere are wide reaching. In the atmosphere $\mathrm{NO}$ is rapidly oxidised to $\mathrm{NO}_{2}$ and in this form plays an essential role in the formation of tropospheric ozone and photochemical smog, and is oxidised to form nitric acid that may then be deposited as acid rain [2]. At ground level, increased concentrations (above $0.06 \mathrm{ppm}$ ) of $\mathrm{NO}_{2}$ can cause respiratory problem [3].

The legislation of $\mathrm{NO}_{\mathrm{x}}$ emission limits in many parts of the world has substantially complicated the process of burner design. Attempts at lowering $\mathrm{NO}_{\mathrm{x}}$ emissions by reducing the flame temperature will lead to reduced flame stability or increased $\mathrm{CO}$ emissions. The lowest $\mathrm{NO}_{\mathrm{x}}$ emission obtainable in a given configuration is always limited by unacceptable stability problems or $\mathrm{CO}$ emissions. Thus the burner design has become a trial-and-error, multi-parameter optimisation process.

Basically there are two techniques of controlling $\mathrm{NO}_{\mathrm{x}}$ : those which prevent the formation of nitric oxide (NO) $[4,5]$ and those which destroy NO from the products of combustion [6-8]. In the present work the later method is employed, i.e. staged combustion.

Staging means that a part of the fuel or oxidizer or both are added downstream of the main combustion zone. In a fuel staging combustor, the fuel is divided to two or more streams and directed into different locations in the combustion chamber in order to burn the fuel in the primary zone under a lean or a rich condition, which is less conducive to $\mathrm{NO}_{\mathrm{x}}$ formation compared to a stoichiometric condition [9]. $\mathrm{NO}_{\mathrm{x}}$ reduction attainable with air or fuel staging usually ranges from 30 to $40 \%$ than that resulting from conventional combustors because the most important factor affecting $\mathrm{NO}_{\mathrm{x}}$ formation is the flame temperature [10-12]. In addition, staging decreases the emissions of $\mathrm{CO}$ and unburned hydrocarbon due to the longer residence time and the burning of $\mathrm{CO}$ and hydrocarbon in the final lean stage [13].

Jaafar et al. [14] investigated the effect of the air staging (secondary air) in an industrial oil burner, and it showed $\mathrm{NO}_{\mathrm{x}}$ and $\mathrm{CO}$ emissions reduction of $30 \%$ and $16.7 \%$, respectively, compared to the non air staging tests. Webster and Schmitz [15] showed that thermal $\mathrm{NO}_{\mathrm{x}}$ is dependent on oxygen concentration inside the combustion chamber. They concluded that with a proper staging, an initial fuel-rich zone in the combustion zone can be created, and hence oxygen concentration decreases, which results in lower $\mathrm{NO}_{\mathrm{x}}$ emission.

\subsection{MATERIALS AND METHOD}

A cylindrical mild steel combustion chamber with internal dimensions of $0.3 \mathrm{~m}$ diameter, $1.0 \mathrm{~m}$ length, and $2 \mathrm{~mm}$ wall thickness was used for this study as shown in Figure 1. The combustion chamber was insulated using $80 \mathrm{~mm}$ thick hy-cast cement. Secondary air was introduced at $400 \mathrm{~mm}$ downstream of the primary air entrance through 10 holes equally spaced circumferentially.

The secondary air flow rate was set at $10 \%$ of the total air flow rate. The air and the fuel were admitted to the combustion chamber through an industrial oil burner. The air was controlled manually using a butterfly valve and measured using an air flow meter, while the fuel flow rate was fixed for a given nozzle used. Nine thermocouples located on the combustion chamber wall and separated axially by $100 \mathrm{~mm}$ were used to measure the axial wall temperature profile. A Baltur BT14GW $140 \mathrm{~kW}$ was used to measure exhaust gas emissions. Carbon monoxide (CO), nitrogen oxides (NOx), sulfur dioxide $\left(\mathrm{SO}_{2}\right)$, and unburned hydrocarbons (UHC) were measured during the experiment. Diesel was used as fuel for all the experiments.

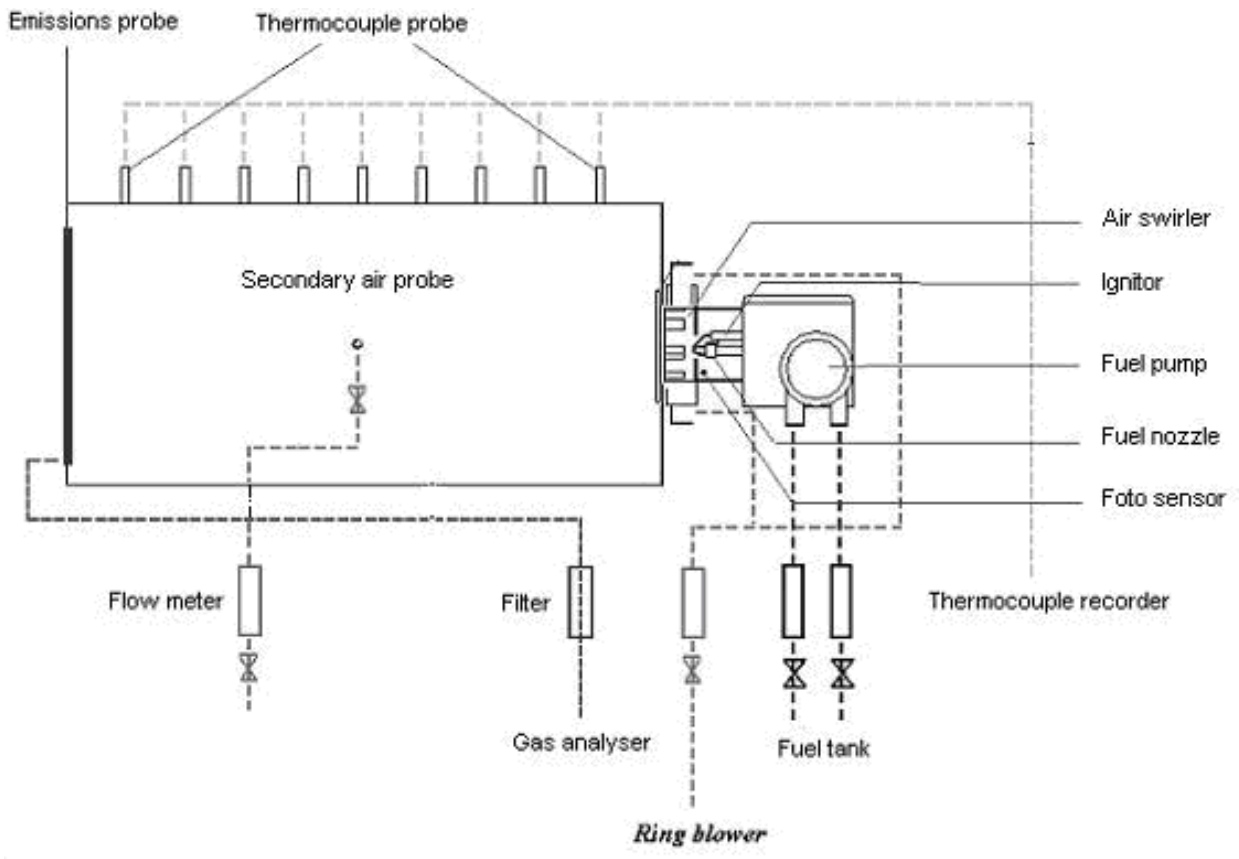

Figure 1 Schematics diagram of the liquid fuel burner experimental test rig 


\subsection{RESULTS AND DISCUSSION}

\subsection{Wall Temperatures Profiles}

The wall temperature of the combustion process plays an important role in determining the amount of gases emitted from the combustion process such as carbon monoxide (CO), and nitrogen oxide $\left(\mathrm{NO}_{\mathrm{x}}\right)$. High temperatures are required to reduce the formation of $\mathrm{CO}$ but it will increase the formation of nitrogen oxides, $\mathrm{NO}_{\mathrm{x}}$.
From Figure 2, it can be seen that the highest temperature occurs at a distance of $400 \mathrm{~mm}$ from the entrance to the combustion chamber. The graph also shows that the wall temperature of the combustion chamber drops at distance downstream from the $400 \mathrm{~mm}$ point from the entrance of the combustion chamber. This is because at the entrance there is a corner recirculation zones where the temperature is much lower. It is expected that the maximum diameter of flame is at the $400 \mathrm{~mm}$ mark. This is why the temperature is highest at this point.

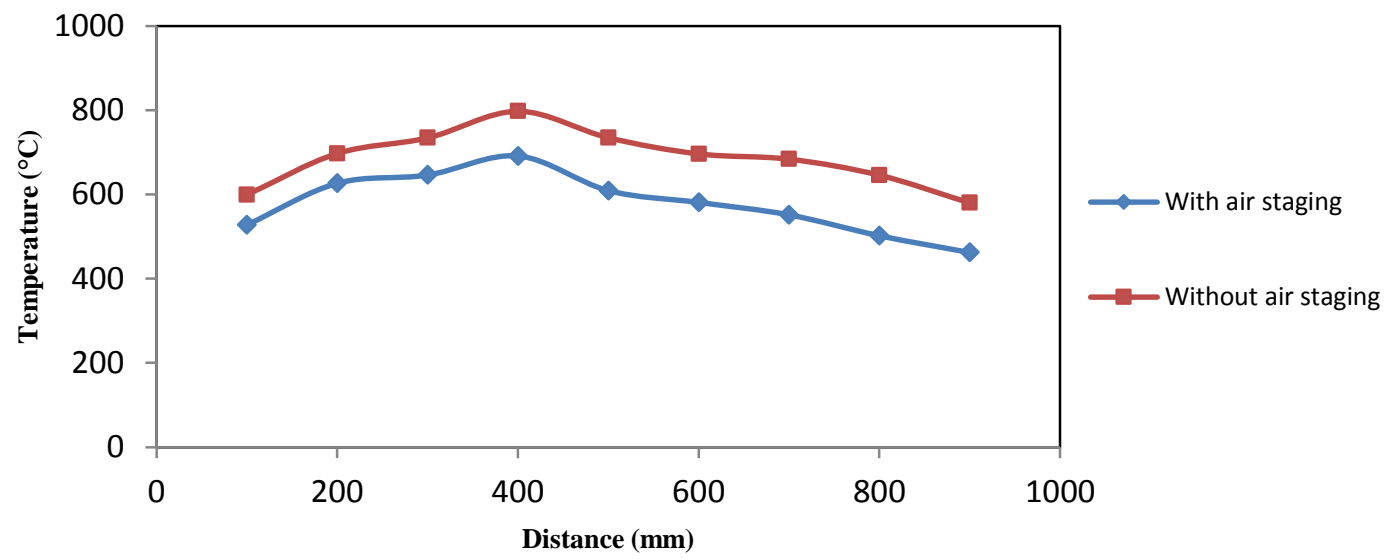

Figure 2 Temperature profiles at equivalence ratio, $\Phi=1.00$

Further downstream, the temperature begins to fall due to the shape of the flame. However, it is observed that by applying the staged air combustion, the peak temperature falls, lower than that without the air staging. The whole profile shows a much lower profile than for the non-staged combustion condition. This is expected since the additional air downstream of the flame reduces the peak temperature. The decrease in the peak flame actually reduces the generation of thermal $\mathrm{NO}_{\mathrm{x}}$ which the product of high flame temperature in the combustion gases. This phenomenon is clearly depicted in Figure 3 for $\mathrm{NO}_{\mathrm{x}}$ emission.

\subsection{The Effect of Air-Staging on the Gaseous Emissions}

Generally, the emissions of $\mathrm{NO}_{\mathrm{x}}$ from the combustion process will increase as the excess air and the temperature increase due to the high oxygen supplied and temperature during the combustion process. The experiment includes introducing secondary air of 15 litre per minute into the combustion chamber at distance of 400 $\mathrm{mm}$ from its entrance. This experiment is carried out at several equivalent ratios, $\Phi$.

Figure 3 shows the emission of $\mathrm{NO}_{\mathrm{x}}$ at all equivalence ratios for conditions with air staging and without air staging. From the graph, it can be observed that the emission of $\mathrm{NO}_{\mathrm{x}}$ is highest at stochiometric condition for both with and without air staging method. This is the common trend obtained for any combustion processes. The emission of $\mathrm{NO}_{\mathrm{x}}$ reduced as the equivalence ratio, $\Phi$, reaches fuel-rich and fuel-lean conditions. By introducing secondary air into the combustion process at the point where the temperature is at peak which is at distance $400 \mathrm{~mm}$, the $\mathrm{NO}_{\mathrm{x}}$ emission was reduced. It can be seen that the concentration of gaseous $\mathrm{NO}_{\mathrm{x}}$ was reduced by at least nine percent and the highest is 16.8 percent, reducing the emission from $95 \mathrm{ppm}$ to $79 \mathrm{ppm}$. At the peak, i.e. stoichiometric condition, $\mathrm{NO}_{\mathrm{x}}$ emission was reduced from $126 \mathrm{ppm}$ to $114 \mathrm{ppm}$. This is due to the reduction of the temperature inside the combustion chamber after the secondary air was introduced. When the flame temperature decreased, this will also decreased the $\mathrm{NO}_{\mathrm{x}}$ emission.

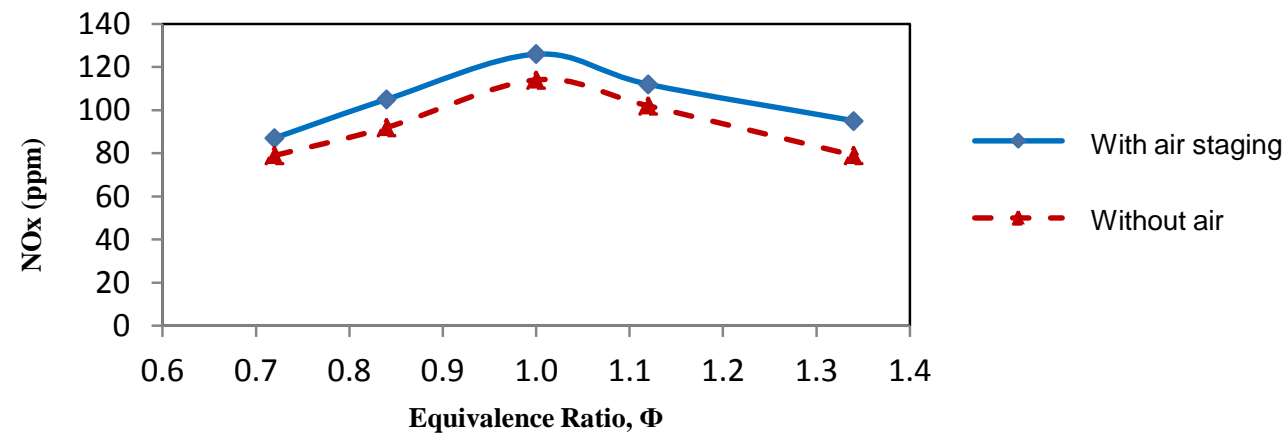

Figure $3 \mathrm{NO}_{\mathrm{x}}$ emission at all equivalence ratios, $\Phi$ 
Figure 4 shows the emission of $\mathrm{CO}$ for both with and without air staging method. The pattern of the graph shows that the emission of $\mathrm{CO}$ increases as the equivalence ratio, $\Phi$, reaches fuel-rich and fuel-lean conditions, with their minimum at the stoichiometric condition. This is inline with the general trend obtained from any combustion processes where at rich condition, there is not enough air to reduce $\mathrm{CO}$ to $\mathrm{CO}_{2}$ whereas at lean condition, equilibrium $\mathrm{CO}$ was formed. When secondary air was introduced into the combustion process, it can be seen that the emission of $\mathrm{CO}$ is slightly reduced. The maximum reduction was obtained at equivalence ratio of 0.84 where $\mathrm{CO}$ emission was reduced by around 32 percent, the highest as compared to all other emissions. This is due to the excess of unburned fuel gone through oxidation by the secondary air injected. At other equivalence ratios, the reductions were moderate except for equivalence ratio of 0.72 .

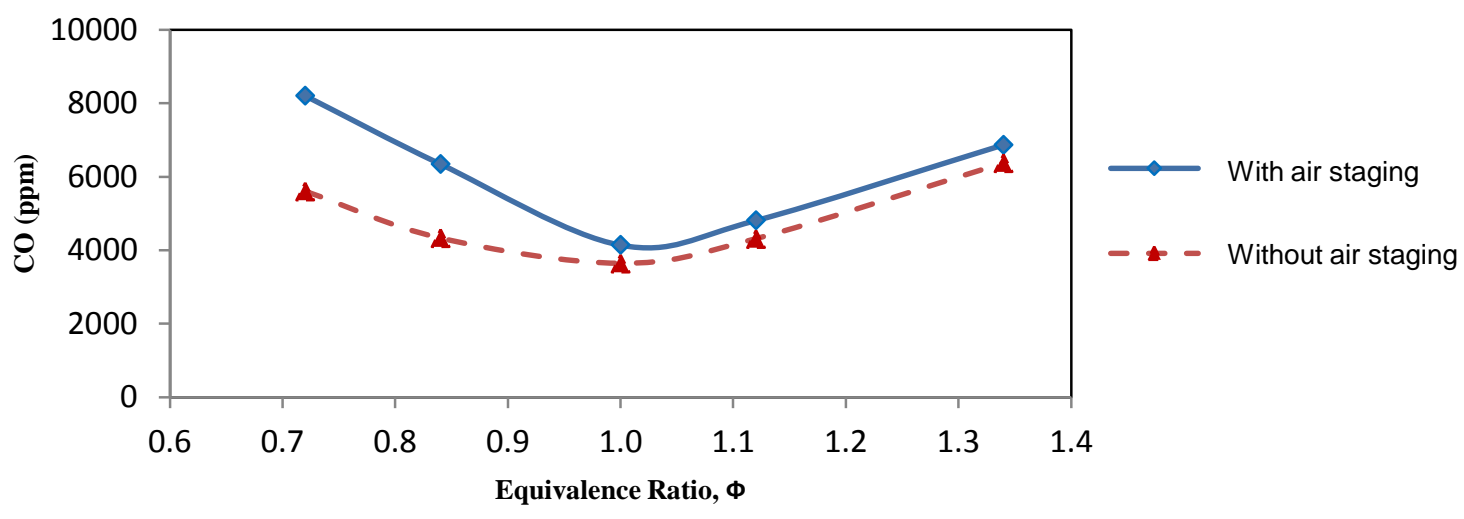

Figure $4 \mathrm{CO}$ emission at all equivalence ratios, $\Phi$

Figure 5 shows the emission of $\mathrm{SO}_{2}$ at all equivalence ratios. The pattern of the graph shows that the emission of $\mathrm{SO}_{2}$ decreases as the equivalence ratio, $\Phi$, reaches fuel-rich and fuel-lean conditions for both with and without air staging method, with its peak at the stoichiometric condition. Figure 5 also shows that the air staging method does not favor in reducing the emissions of $\mathrm{SO}_{2}$ because of the excess oxygen in secondary air acts to react with sulphur to produce $\mathrm{SO}_{2}$. The emission of $\mathrm{SO}_{2}$ actually increased at several points except at stoichiometric where the reduction is around seven percent. Elsewhere, $\mathrm{SO}_{2}$ either was reduced marginally or it was actually increased. Generally, it can be observed that the trend for $\mathrm{SO}_{2}$ profile is similar to that of the $\mathrm{NO}_{\mathrm{x}}$ profile.

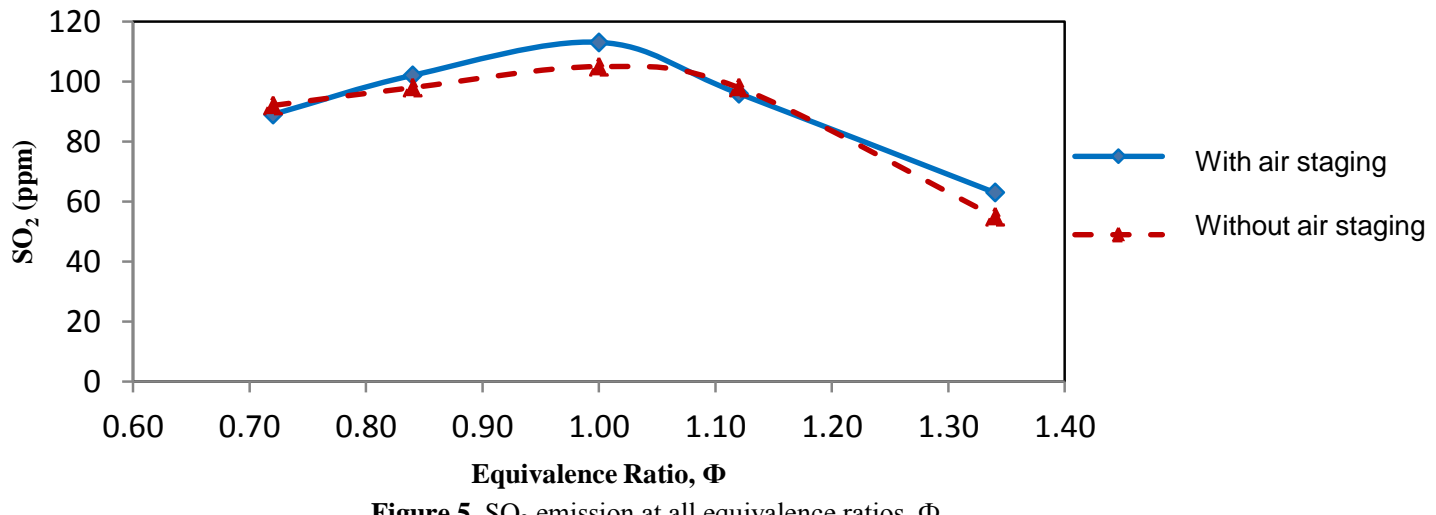

Figure 6 shows the formation of UHC emission at different values of equivalence ratio, $\Phi$. It shows that the emission of UHC decreases as the value of equivalence ratio, $\Phi$ reaches fuel-rich and fuel-lean conditions and it also has similar pattern if compared to $\mathrm{CO}$ emission graph. As the secondary air is introduced, the UHC emission was slightly decreased. However, the reduction is also quite small as obtained for $\mathrm{SO}_{2}$ where the largerst reduction for UHC emission with air staging is around 10 percent at stoichiometric condition. Elsewhere, the reduction is quite small if not increased. This results are inline with work done by Mohd Jaafar et al. [16]. They showed the same trends for UHC and $\mathrm{SO}_{2}$ emissions for diesel fuel tests. 


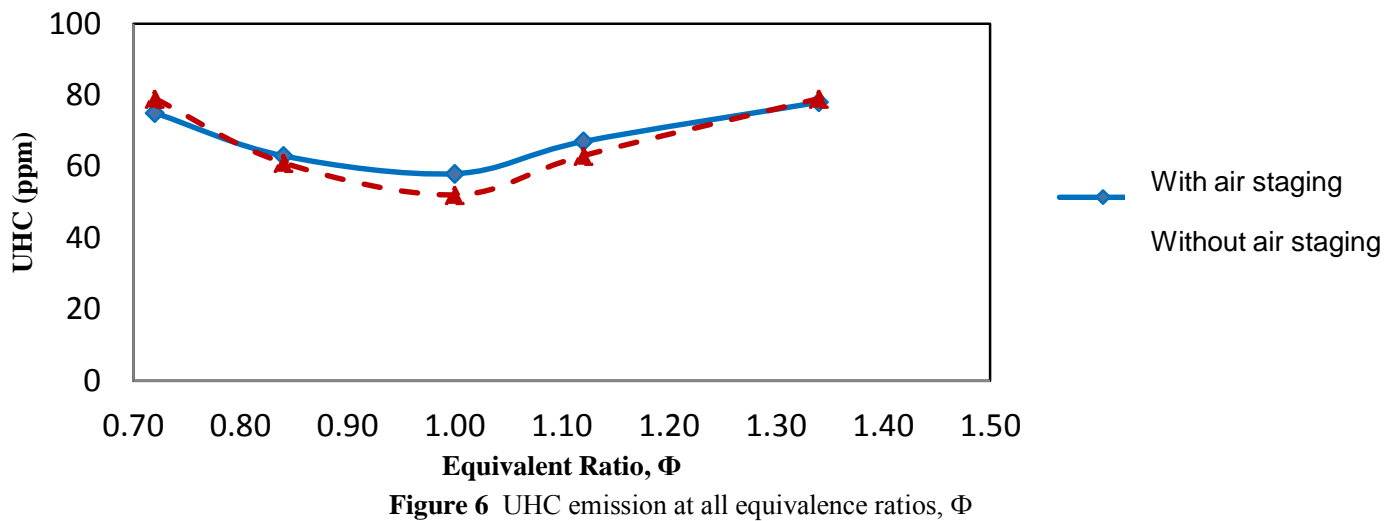

\subsection{CONCLUSSION}

For the air staging method, the secondary air was introduced into the combustion chamber at 10 percent from the total air flow rate of 150 litre per minute (around 15 litre per minute) at the distance of $400 \mathrm{~mm}$ from the entrance to the combustion chamber. From the results obtained, it can generally be concluded that by using air staging method; the flame temperature inside the combustion chamber was reduced, hence reducing the concentration of most gaseous emissions. Significant reductions were obtained for two major gases: 31.8 percent reduction for $\mathrm{CO}$ emission and 16.8 percent for $\mathrm{NO}_{\mathrm{x}}$. However the air staging method was not so effective in reducing $\mathrm{UHC}$ and $\mathrm{SO}_{2}$ emissions, with only slight reductions at several equivalence ratios.

\section{Acknowledgements}

The authors would like to thank the Ministry of Science, Technology and Innovation for awarding a research grant (project number: 03-01-06-SF-1033) to undertake this project. The authors would also like to thank Faculty of Mechanical Engineering, Universiti Teknologi Malaysia for providing the research facilities and space to undertake this work.

\section{References}

[1] Andrews, G. E., Alkabie, H. S., Abdul Aziz, M. M., Abdul Hussain, U. S., Al Dabbagh, N. A., Ahmad, N. A., Ali Al Shaikly, A. F., Kowkabi, M. and Shahabadi, A. R. 1992. High Intensity Burners with Low NOx Emissions. Proc. Instn. Mech. Engrs. 206: 3-17.

[2] Harrison, R. M. 1990. Important Air Pollutants and Their Chemical Analysis. Pollution: Causes, Effects and Control. London: Royal Society of Chemistry. 156-175.

[3] World Health Organisation. 1987. Air Quality Guidelines for Europe WHO Regional Publications, European Series No. 23, ISBN 92890 1114 9. WHO Regional Office for Europe: Copenhagen.
[4] Eide, L. I. and D. W. Bailey. 2005. Precombustion Decarbonisation Processes. Oil \& Gas Science and Technology - Rev. IFP. 60(3): 475484.

[5] FukuShima, S. and Y. Suzukawa. 2002. Eco-friendly Regenerative Burner Heating System Technology Application and Its Future Prospects. NKK Technical Review. 87: 30-37.

[6] Abul Hossain, K., M. N. Mohd-Jaafar, K. B. Appalanidu, A. Mustafa, and F. N. Ani. 2005. Application of Urea based SNCR System in the Combustion Effluent Containing Low Level of Baseline Nitric Oxide. Environmental Technology. 26(3): 251-259.

[7] Sanisah Saharin and M. N. Mohd-Jaafar. 2008. Emissions Reduction of an Oil Burner by Air Staging. International Conference on Environment 2008, USM Malaysia, 15-17 December 2008.

[8] Rowlan, S. J. 2002. NOx Control on Preheat and Radiant Furnaces at Nucor Steel Mills through Urea SNCR, SCR, and Hybrid Processes. ICAC Forum, Houston, Texas, USA, February 12-13.

[9] Sun, J.; Caton, J. A.; Jacobs, T. J. 2010. Oxides of Nitrogen Emissions from Biodiesel-fuelled Diesel Engines. Prog. Energy Combust. Sci. 36: 677-95.

[10] Waibel, R. T.; Athens, L.; Claxton, M. 1995. Effect of Fuel Composition on Emissions from Ultra-Low NOx Burners. American Flame Research Committee, Fall International Symposium, Monterey, CA.

[11] Streichsbier, M.; Dibble, R. W. 1997. Engineers AIoC, Meeting AIoCE Non Catalytic NO (x) Removal from Gas Turbine Exhaust with Cyanuric Acid in a Recirculating Reactor. American Institute of Chemical Engineers:

[12] Nimmo, W.; Patsias, A.; Williams, P. 2006. Enhanced NOx Reduction with SO2 Capture under Air-Staged Conditions by Calcium Magnesium Acetate in an Oil-Fired Tunnel Furnace. Energy Fuels. 20: 1879-85.

[13] Beer, J. 1995. Clean Combustion in Gas Turbines: Challenges and Technical Responses--A Review. J. Inst. Energy. 68: 2-10.

[14] Jaafar, M. N. M.; Ishak, M. S. A.; Saharin, S. 2010. Removal of NOx and CO from a Burner System. Environ. Sci. Technol. 44: 3111-15.

[15] Webster, T.; Schmitz, R. 2000. Determining Optimum Combustion Solutions to Emissions Concerns for New and Existing Boilers. TODD Combustion, John Zink Co LLC.

[16] Jaafar, M. N. M., Yehia A. Eldrainy, Muhammad Faiser Mat Ali, W. Z Wan Omar, and Mohd Faizi Arif Mohd Hizam. 2012. Combustion Performance Evaluation of Air Staging of Palm Oil Blends. Environmental Science \& Technolology. 46: 2445-2450. 